\title{
Multi-method Active Learning Approach: improving the educational experience in Pharmaceutical Drug Development
}

\author{
Herdeiro $\mathrm{MT}^{\star 1}$, Teixeira Rodrigues $\mathrm{A}^{1,2}$, Ferreira $\mathbf{M}^{1}$, da Cruz e Silva OAB ${ }^{1}$ and Fardilha $\mathbf{M}^{1,3}$ \\ ${ }^{1}$ Center for Cell Biology, University of Aveiro (CBC/UA), Portugal \\ ${ }^{2}$ Faculty of Pharmacy, University of Coimbra (FFUC), Portugal \\ ${ }^{3}$ Signal Transduction Laboratory, Center for Cell Biology, Biology Department and Health Department, University of Aveiro
}

\begin{abstract}
Background: Improve educational experience, teaching effectiveness and learning outcomes remains one of the major educational challenges nowadays. Purpose: To determine the effect of organizing and teaching the Pharmaceutical Drug Development curricular unit using a Multi-method Active Learning Approach, MALA, as a novel teaching/learning strategy. Methods: MALA involved several different activities about pharmaceutical legislation, medicines production and validation process, Common Technical Document, and others, and the evaluation of this active learning approach was made in two ways: students' performance (grades), and students' evaluation regarding the curricular unit and the teachers' performance. Results: Results revealed two main important aspects of the implementation of MALA: (i) the implementation of MALA showed high rates of students' satisfaction regarding the curricular unit and teachers' performance; (ii) student's performance (grades) were very high, revealing excellent teaching/ learning results. Conclusion: The present study fostered the concept that the MALA- learning approach should contribute to knowledge- enhancing in the pharmaceutical practice and could encourage integration of the students' learning skills in the future career, thus stimulating the flexibility in learning.
\end{abstract}

Keywords: MALA, Active learning approach, PBL, pharmaceutical drug development.

\section{INTRODUCTION}

Improve educational experience, teaching effectiveness and learning outcomes (LO) remains one of the major educational challenges nowadays. Surrounding pharmaceutical education, the Accreditation Council for Pharmacy Education refers that it is fundamental to implement active learning methods in under graduation process to improve learning outcomes. ${ }^{1}$

Pharmaceutical Drug Development (PDD) constitutes a challenging subject to be learned by the undergraduate students who face difficulties in the integration of the theoretical and practical concepts of the discipline. Traditional learning methods are characterized by the simple transmission of information (theoretical lectures and teaching materials) and an exam at the end of the semester.

Active learning approaches, as problem-based learning (PBL), have been developed and widely used in higher education, ${ }^{2}$ aiming to improve the educational experience and outcomes in opposition to the traditional methods. Firstly, these learning processes pretend to be active efforts and the student must learn in different ways. ${ }^{3}$ This learning technique is based on four key principles (constructive, self-directed, collaborative and contextual learning process) and it implies the verbalization, co-construction, joint support and appreciation between the participants. ${ }^{4}$ Here students
DOI: 10.5530/ijper.48.3.4

Address for correspondence:

Prof. Maria Teresa Herdeiro Health Sciences Department, Agra do Crasto - edifício 30, 3810-193 Aveiro, Portugal

Phone: +351234370200

Fax: +351234370985

E-mail: teresaherdeiro@ ua.pt

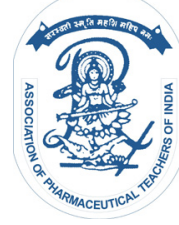

www.ijper.org 
discover, research, process and apply information, ${ }^{5}$ and also play a pivotal role on planning, monitoring and evaluating the educational method. ${ }^{6,7}$ The characteristics considered essential in the PBL method are the problems as an incentive for learning, tutors as facilitators and group working as motivation for interaction, where tutors and consultants should stimulate students towards self-directed learning and to explore the knowledge profoundly. ${ }^{4}$

Accordingly, in 2006, the Health Sciences Department of Aveiro University (UA) applied a multi-method active learning approach (MALA) ${ }^{8}$ in the PDD curricular unit $(\mathrm{CU})$ instead of teaching in a traditional manner. Thus, the objectives of the study were to determine the effect of organizing and teaching the PDD unit using the MALA as a novel teaching/learning strategy and to assess Biomedical Sciences degree students' performance and evaluation towards this learning process.

\section{MATERIALS AND METHODS}

\section{Educational setting, study population and study period}

In 2006, the Health Sciences Department of UA adopted MALA ${ }^{8}$ in the Biomedical Sciences undergraduate degree. The MALA was thus implemented in the PDD-CU of the second year Biomedical Sciences degree at the UA. The PDD unit was initiated in the year 2007/2008 comprising 15 students. The second year edition, in 2008/2009, accounted for a total of 12 students, the third edition, in 2009/2010, involved a group of 13 students, the fourth edition, in 2010/2011, included 16 students, and the fifth edition included 19 students (2012/2013). In 2011/2012, PDD wasn't taught because of restructuring matters of the Biomedical Sciences Degree.

It is important to refer that MALA was implemented in the first year of the Biomedical Sciences degree. Therefore, the second-year undergraduate students were familiar with this active learning method.

\section{The traditional method}

Traditionally, PDD is taught through lectures and the assessment is performed at the end of the semester, when students face with a great volume of new concepts that should be memorized and understood in a short period of time, increasing the difficulty of transpose theoretical concepts into practice. Moreover, the lack of motivation, participation and autonomy can contribute to the failure of the learning process.

\section{MALA - Multi-method Active Learning Approach}

The preceptor responsible for the PDD- CU is a scientific expert in pharmaceutical sciences, with expertise in Regulatory Affairs from Portuguese Pharmacists' Professional Organization.

In order to implement MALA, competence- based LO were defined and structured by the consultant, which implied the transference of the learning conscientiousness to the learners. ${ }^{9}$ Consultant defined the LO according with the syllabus defined in the Biomedical Sciences degree.

Table 1 presents the competences, LO and specific objectives related to each PAT (Performance, Attributes and Tasks) defined for this CU. Also, for each PAT, was defined the learning activity, the learning approaches used and the skills development pretended (Table 2).

The MALA included four main activities (Figure 1):

\section{Tutorial sessions}

The course unit on PDD included tutorial sessions (TS) dealing with the general context of the CU. The intent was to stimulate the students to ascertain about the subject, and also to promote independent study and active research:

- The first problem (Problem 1) presented to the students addressed the competencies and activities of the institutions that regulate the pharmaceutical activity in terms of National regulation, National Authority of Medicines and Health Products I.P. (INFARMED), along with European regulation, European Medicines Agency (EMA), as well as the guidelines for Technical Requirements for Registration of Pharmaceuticals for Human Use, referred in the International Conference of Harmonization ( $\mathrm{ICH}$ );

- The second problem (Problem 2) addressed the European legislation, Eudralex (Volume 2), of Pharmaceutical Legislation, Notice to applicants and regulatory guidelines medicinal products for human use, presentation and content of the Common Technical Document (CTD), procedures for marketing authorization, variations and renewal of CTD. Given the specificity of the proposed problem, adaptations were made accordingly to the students' difficulties in the resolution of Problem 1.

The PBL sessions started with the discussion of problems, to clarify the incomprehensible terms and concepts, followed by the definition of the problem by the students. The problems were further critically analyzed, 


\section{Table 1: Competences, learning outcomes, and specific objectives related to Pharmaceutical Drug Development.}

\begin{tabular}{|c|c|c|c|}
\hline Competency & Learning outcome (LO) & $\begin{array}{c}\text { Performance, } \\
\text { Attributes and } \\
\text { Tasks (PAT) }\end{array}$ & Specific learning objectives \\
\hline $\begin{array}{l}\text { To identify the } \\
\text { European and } \\
\text { National institutions } \\
\text { that regulate the } \\
\text { drug marketing } \\
\text { authorization }\end{array}$ & $\begin{array}{l}\text { To identify the National } \\
\text { and European } \\
\text { institutions that regulate } \\
\text { the introduction of a } \\
\text { drug in the market } \\
\text { and to recognize their } \\
\text { competences }\end{array}$ & PAT 1 & $\begin{array}{l}\text { To identify National Authority of Medicines and Health Products, } \\
\text { IP (INFARNED*) as the agency responsible for monitor, assess } \\
\text { and regulate all activities relating to human medicines and health } \\
\text { products for the protection of Public Health } \\
\text { To identify the European Medicines Agency (EMA†), } \\
\text { decentralized body of the European Union responsible for } \\
\text { medicines regulation } \\
\text { To recognize the INFARMED IP competencies } \\
\text { To recognize the EMA competencies }\end{array}$ \\
\hline & $\begin{array}{l}\text { To identify and recognize } \\
\text { the National and } \\
\text { European legislation } \\
\text { of pharmaceutical drug } \\
\text { development }\end{array}$ & PAT 2 & $\begin{array}{l}\text { To use informatics tools to research, and collect regulation } \\
\text { and technical- scientific information in the pharmaceutical } \\
\text { development } \\
\text { To identify and recognize the national legislation that regulates } \\
\text { pharmaceutical development } \\
\text { To identify and recognize the European legislation that regulate } \\
\text { pharmaceutical development }\end{array}$ \\
\hline $\begin{array}{l}\text { To evaluate, } \\
\text { analyze, organize } \\
\text { and construct the } \\
\text { documentation } \\
\text { relative to } \\
\text { the Chemical- } \\
\text { pharmaceutical } \\
\text { and biological } \\
\text { information for } \\
\text { chemical active } \\
\text { substances and } \\
\text { biological medicinal } \\
\text { products" - Module } \\
3 \text { of CTD }\end{array}$ & $\begin{array}{l}\text { To recognize the } \\
\text { Common Technical } \\
\text { Document (CTD } \ddagger \text { ) in } \\
\text { particular the format and } \\
\text { content of module } 3 \text { of } \\
\text { the CTD }\end{array}$ & PAT 3 & $\begin{array}{l}\text { To recognize the CTD } \\
\text { To recognize the format and content of module } 3 \\
\text { To be able to research and analyze the information related with } \\
\text { the parameters defined in module } 3 \\
\text { To organize and construct module } 3 \text {, with the information } \\
\text { obtained through the active substance identification and assay } \\
\text { according to the European Pharmacopeia } \\
\text { To know the concept of the manufacturing process validation } \\
\text { To know the concept of analytical procedure validation } \\
\text { To know the regulation for the stability protocol development }\end{array}$ \\
\hline
\end{tabular}

* INFARMED, National Authority of Medicines and Health Products, IP; EMA $†$, European Medicines Agency; $\Varangle C T D$, Common Technical Document

Pharmaceutical Drug Development

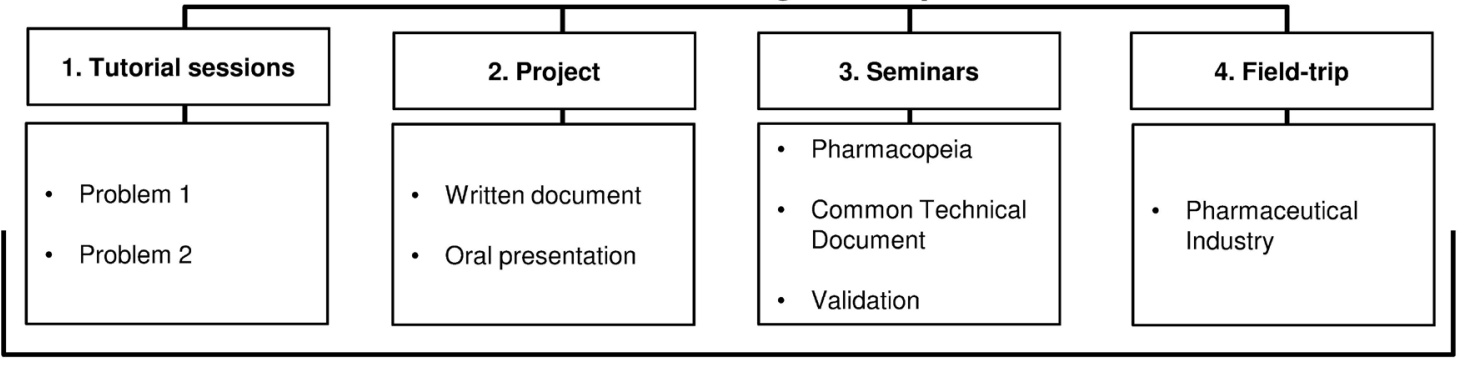

Figure 1: Multi-method active learning approach (MALA) activities 
Table 2: Learning approaches and skills development, associated with each learning activity

\begin{tabular}{|c|c|c|c|c|c|c|}
\hline \multirow{2}{*}{$\begin{array}{l}\text { Performance, } \\
\text { attributes and } \\
\text { tasks (PAT) }\end{array}$} & \multicolumn{6}{|c|}{ Learning activity } \\
\hline & Problem 1 & Problem 2 & Project & $\mathrm{CEA}^{\S}$ & Learning approaches & Skills development \\
\hline PAT 1 & $x$ & $x$ & & & Problem-based learning a & \\
\hline PAT 2 & $\mathrm{x}$ & $\mathrm{x}$ & & & Problem-based learning a & $\begin{array}{l}\text { a) Reflection, reasoning, discussion, } \\
\text { analysis, synthesis, critical thinking, }\end{array}$ \\
\hline \multirow[t]{2}{*}{ PAT 3} & $x$ & $x$ & & $x$ & $\begin{array}{l}\text { Problem-based learning }{ }^{a} \\
\text { Expert- driven learning }^{b}\end{array}$ & $\begin{array}{l}\text { information access and retrieval and oral } \\
\text { communication skills. }\end{array}$ \\
\hline & & & & & Hands on experience ${ }^{c}$ & $\begin{array}{l}\text { b) Listening, reflection, discussion, } \\
\text { analysis, synthesis. }\end{array}$ \\
\hline \multirow[t]{4}{*}{ PAT 4} & & & $x$ & $x$ & Expert- driven learning ${ }^{b}$ & \\
\hline & & & & & Hands on experience ${ }^{c}$ & c) Procedural and practical skills, \\
\hline & & & & & Learning by teaching ${ }^{d}$ & skills. \\
\hline & & & & & & $\begin{array}{l}\text { d) Critical thinking, information } \\
\text { access and retrieval, oral and written } \\
\text { communication, capacity to explore }\end{array}$ \\
\hline
\end{tabular}

\$CEA (Complementary Education Activities).

thus activating prior knowledge that facilitates the processing and clarification of new information.

\section{Project}

As a complementary approach in the PDD unit, it was proposed to the students that they should develop a project covering a specific subject within the framework of the CU. Therefore, students were invited to examine, in detail an active substance mentioned in the European Pharmacopeia. Tutor supported the project progress, by directing the research to specific paths, and to accomplish specific objectives within the scheduled deadline. In addition, students were instigated to follow a line of research within the recommended literature. Founded on the literature review, it was defined the production of a written report, correspond to the module 3 of the CTD, to be presented to the rest of the class in PowerPoint format. Both the written report and the oral presentation were communicated in the English language, and the latter had the duration of 10 minutes with 5 minutes of open discussion with the rest of the class. This process was monitored by the tutor and contributed to an open line of communication.

The evaluation factor included, not only, the performance during the presentation, but also, the active participation in the discussion of other groups' presentations. Since the class was divided into groups, it was ensured that all students had the opportunity to actively participate in each project presentation, to learn more about a specific subject matter, and to develop their capacity of interaction and mutual aid within the group. Also, the students acquired relevant knowledge about panoply of subjects, and developed skills closely related to critical opinion.

\section{Seminars}

Three seminars were included in the CU:

- Pharmacopeias: the first seminar was given by a pharmacist with a doctoral degree in Pharmaceutical Sciences. This seminar was dedicated to the Pharmacopeias, and students had the opportunity to consult and interpret the information mentioned in the Pharmacopeias. The students dealt with the European, Portuguese, British and United American Pharmacopeia, denoting the particularities of each one.

- CTD: the second seminar was given on the theme CTD by a specialist in Pharmaceutical Regulatory Affairs. During the seminar, the specialist focused on the five modules of the CTD, especially, module 3 , demonstrating with practical information.

- Validation of analytical procedures and manufacturing process: the third seminar approached the validation process and was given by a Chemical Engineer/Pharmacist working in a Pharmaceutical company.

\section{Field-trip}

Complimentarily, the PDD unit comprised a field-trip to a pharmaceutical enterprise where the students had contact with the drug manufacturing process. Moreover, the students were invited to integrate the process of quality control, collecting and analyzing the samples 
(in-process control), under the supervision of the head of department. These activities were of extraordinary importance, allowing the in loco visualization of the manufacturing equipment, procedures and general work environment. The students also had the opportunity to recognize the process underlying to the stability, control of the drug manufacturing rooms (including the temperature, humidity, and pressure), the water quality control, plus the complete circuit of raw-materials entrance and the outlet of the finished-product. Overall, the students were allowed to explore the main quality procedures, the good-quality laboratory practices, manufacturing and warehouse of the drugs, so they could understand the drug production in the context of a real work environment.

\section{Evaluation and assessment}

\section{Students' performance}

Different assessment tools were used for each PAT (Table 3). The evaluation was defined at the begin- ning of the year, and presented to the students on the first day of classes, as well as the tutorial chronogram, project work, field- trip and seminars, programmatic contents, and recommended literature. In relation to the assessment, $20 \%$ of the evaluation corresponded to TS, through a schedule grid previously established for this type of assessment that contemplated, among other factors, the following: assiduity, punctuality, individual work, sharing/analysis/synthesis and integration of information. The remaining $80 \%$ were distributed in the PAT component, more specifically PAT 1, 2, and 3, which were evaluated by final exam and had a weighting factor of 1, and PAT 4, that was assessed by the projects elaboration and presentation and had a weighting factor of 2. These techniques are integrated in the active learning, where the students are profoundly involved, over simply listening to a lecture, thus developing skills involved in higher- order thinking, and students embrace activities (analysis/discussion/evaluation) to explore their own attitudes and values.

\section{Table 3: Performance, Attributes and Tasks assessment}

\begin{tabular}{|c|c|c|}
\hline \multicolumn{2}{|c|}{ Performance, Attributes and Tasks (PAT) } & \multirow{2}{*}{$\begin{array}{l}\text { Satisfaction Criteria } \\
\text { To identify the acronyms/meaning and to recognize the competences related } \\
\text { to national pharmaceutical drug development. }\end{array}$} \\
\hline PAT 1 & Fair & \\
\hline & Good & $\begin{array}{l}\text { Additionally to the above requirements, this should be extended to the } \\
\text { European pharmaceutical drug development. To recognize several actuation } \\
\text { areas of INFARMED", directly related to pharmaceutical drug development: } \\
\text { marketing authorization submission process, variations and renewal } \\
\text { requirement. }\end{array}$ \\
\hline & Very Good & $\begin{array}{l}\text { Additionally to the above requirements, to know the different competences } \\
\text { areas of } \mathrm{EMA}^{\dagger} \text {, directly related to pharmaceutical drug development: marketing } \\
\text { authorization submission process, variations and renewal requirement. }\end{array}$ \\
\hline & Excellent & $\begin{array}{l}\text { Additionally to the above requirements, to describe the competences of those } \\
\text { institutions in relation to other actuation areas, such as: reimbursement and/or } \\
\text { pharmacovigilance and/or inspection. }\end{array}$ \\
\hline \multirow[t]{4}{*}{ PAT 2} & Fair & $\begin{array}{l}\text { To recognize the INFARMED site, and the current National legislation (Dec. } \\
\text { Lei } 176 / 2006 \text { of } 30^{\text {th }} \text { August) in pharmaceutical development area. }\end{array}$ \\
\hline & Good & $\begin{array}{l}\text { Additionally to the above requirements, to know the EMA and ICH site, the } \\
\text { European legislation in the pharmaceutical drug development "Medicinal } \\
\text { Products for Human Use" and guidelines. }\end{array}$ \\
\hline & Very Good & $\begin{array}{l}\text { Additionally to the above requirements, to identify at the INFARMED and } \\
\text { Informed website, compiled information. }\end{array}$ \\
\hline & Excellent & $\begin{array}{l}\text { Additionally to the above requirements, to consult the EMA site in relation } \\
\text { to the legislation, and information about the commercialized drug in the EU } \\
\text { countries. }\end{array}$ \\
\hline \multirow[t]{4}{*}{ PAT 3} & Fair & To identify module 3 of the $C T D^{\ddagger}$, either in the national or European legislation. \\
\hline & Good & $\begin{array}{l}\text { Additionally to the above requirements, to know the } 5 \text { modules of the CTD, } \\
\text { and in relation to module } 3 \text {, recognize the format, index and content, either in } \\
\text { the National and European legislation. }\end{array}$ \\
\hline & Very Good & $\begin{array}{l}\text { Additionally to the above requirements, to be able to research information } \\
\text { about the construction of module } 3 \text {. }\end{array}$ \\
\hline & Excellent & $\begin{array}{l}\text { Additionally to the above requirements, and in relation to module } 3 \text { of the CTD, } \\
\text { to be able to analyze the information obtained by bibliographic research. }\end{array}$ \\
\hline
\end{tabular}




\begin{tabular}{|c|c|c|}
\hline \multicolumn{2}{|c|}{ Performance, Attributes and Tasks (PAT) } & \multirow{2}{*}{$\begin{array}{l}\text { Satisfaction Criteria } \\
\text { To recognize the module } 3 \text { of the CTD, in format, index, and content, } \\
\text { and to be able to organize and construct, in correct technical- scientific } \\
\text { English: } 1 \text { ) the general information about the active substance (structural } \\
\text { elucidation, impurity and other characteristics; } 3 \text { ) active substance control } \\
\text { (specifications, analytical procedures; } 3 \text { ) bibliographic references. }\end{array}$} \\
\hline PAT 4 & Fair & \\
\hline & Good & $\begin{array}{l}\text { Additionally to the above requirements, and in relation to module } 3 \text { of } \\
\text { the CTD, to construct the information concerning: 1) complete product } \\
\text { description and composition; 2) pharmaceutical development; } 3 \text { ) complete } \\
\text { product control/ drug (specifications/ analytical procedure; 4) final product } \\
\text { container. }\end{array}$ \\
\hline & Very Good & $\begin{array}{l}\text { Additionally to the above requirements, and in relation to module } 3 \text { of the } \\
\text { CTD, to construct the information related to: } 1 \text { ) active substance synthesis } \\
\text { process; 2) complete product/drug manufacturing process; } 3 \text { ) stability } \\
\text { protocol. }\end{array}$ \\
\hline & Excellent & $\begin{array}{l}\text { Additionally to the above requirements, in relation to module } 3 \text { of the CTD, } \\
\text { to construct the information related to: analytical procedure validation for } \\
\text { the active substance and the complete product; } 2 \text { ) manufacturing validation } \\
\text { process, according to module } 3 \text { of the CTD. }\end{array}$ \\
\hline
\end{tabular}

* INFARMED, National Authority of Medicines and Health Products, IP; ;EMA, European Medicines Agency; ${ }^{\ddagger}$ CTD, Common Technical Document

About students' global evaluation (grades of the year), it was made using a quantitative scale, from 0 to 20 , which converge the evaluation of each PAT and the tutorial sessions. Five years were available for the analysis: $2007 / 2008,2008 / 2009,2009 / 2010,2010 / 2011$ and 2012/2013.

Students' evaluation

UA recently implemented a quality assurance system that included students' opinion about the CU and about teachers' performance. Students were asked to respond to a questionnaire where each question was rated on a 9-point Likert scale, from 1 (disagree) to 9 (agree). Three years were available for the analysis: 2009/2010, $2010 / 2011$ and $2012 / 2013$. The quality assurance system was only implemented in the second semester of $2008 / 2009$, and because of it, we don't have results from 2007/2008 and 2008/2009 (PDD is a CU from the first semester).

The students' opinion regarding the $\mathrm{CU}$ was evaluated in five different variables:

A. Global functionality of the CU;

B. Adequacy of the CU proposed activity to the defined objectives;

C. Students' assiduity degree with the tutorial classes;

D. Global satisfaction degree concerning student performance;

E. Motivation to the CU.

The students' opinion regarding the teachers' performance was evaluated in four different variables: i. Global evaluation of the teacher' performance;

ii. Fulfillment of the evaluation standing rule according to the students;

iii. Relationship between the students and teacher;

iv. Creation of learning favorable atmosphere.

\section{RESULTS}

\section{Students' performance}

About students' grades, in $2007 / 2008$ the mean was 14 , in $2008 / 2009$ was 14.8 , in $2009 / 2010$ was 16.1 , in $2010 / 2011$ was 15.4 and in 2012/2013 was 15.8. In general, the grades have increased during the years and in $2009 / 2010$ we have obtained the highest classification (16.1).

Figure 2 presents the distribution of students grades on a qualitative scale obtained in the different components of PAT evaluated in the PDD- CU. Comparing students' performance in each PAT, PAT 1 and PAT 4 revealed higher rates in all years analyzed.

\section{Students' evaluation}

In relation to questionnaires, the results were transposed into a percentage (Figure 3).

As demonstrated for all years analyzed, students' evaluation was higher than $70 \%$ for all variables analyzed. About the CU evaluation, students' assiduity degree with the tutorial classes (C) and global satisfaction degree concerning student performance (D) present a rate superior of $75 \%$. Teachers' performance evaluation 


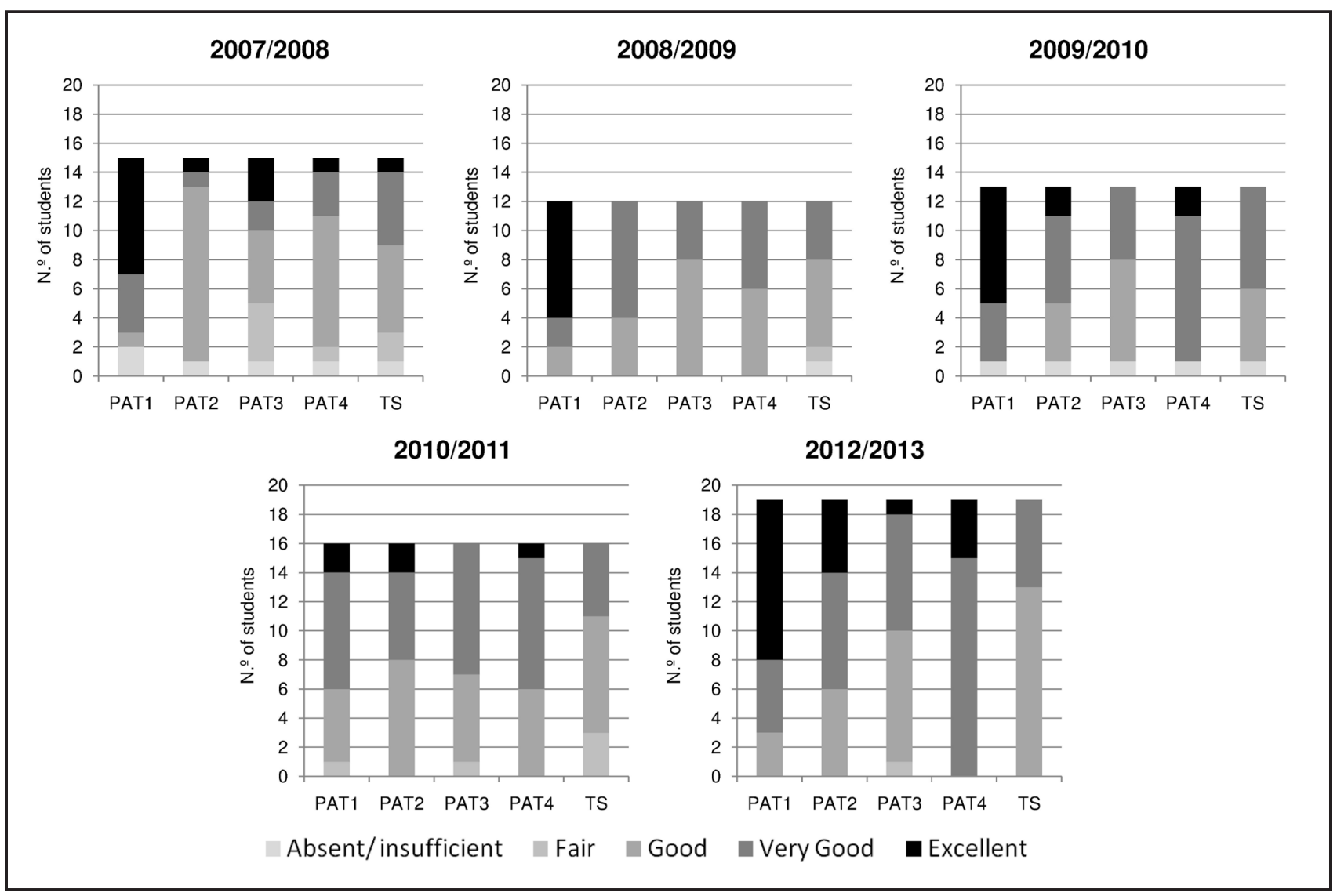

Figure 2: Distribution of students' grades (qualitative scale) obtained in the different Performance, Attributes and Tasks (PAT) evaluated.

revealed for all variables, in 2009/2010 and 2010/2011, satisfaction levels higher than $80 \%$. Comparing all years analyzed, the level of students' satisfaction decreases, in general, over time.

\section{DISCUSSION}

This study examines the effectiveness of using MALA as a novel learning approach for PDD, and two main conclusions can be made: (i) the implementation of MALA revealed high rates of students' satisfaction regarding the CU and teachers' performance; (ii) student's performance (grades) are very high revealing excellent teaching/learning results.

Our results revealed that the quantitative evaluation of the students' performance increased over time, from 14 (2007/2008) to $15.8(2012 / 2013)$. It's also important to refer that higher rated PAT's were the PAT 1 and PAT 4. PAT 1 is related to Portuguese legislation surrounding medicines, which is very interesting for the students, and PAT 4 is about the project elaboration, which concern the practical application of the knowledge acquired before.
The PDD unit was re-structured and taught accordingly with this innovative learning strategy, comprising a variety of active- learning educational techniques organized following the PBL method associated with complementary education activities (CEA), thus including problems on the subject matter, and a project consisting in the elaboration of the model on the CTD. Moreover, the $\mathrm{CU}$ was complemented with seminars presented by specialists on drug development/regulatory affairs, and a field- trip to the pharmaceutical industry of drug manufacturing.

The PBL learning approach encouraged students to integrate preliminary explanations and formulate learning questions as suggested in several studies. ${ }^{10-13}$ Complementarily, students enhanced the self- directed learning skills in the sense that it improved the exploitation of literature to access information, thus addressing the proposed LO., ${ }^{4,13}$ Effectively, in 2005, Dolmans et al. ${ }^{4}$ revealed that learning, in the context of PBL, stimulates the transference of knowledge, and motivates selfdirected and lifelong learning. Furthermore, the number of students that attended the PBL sessions was crucial to the success of the learning process. ${ }^{14}$ 

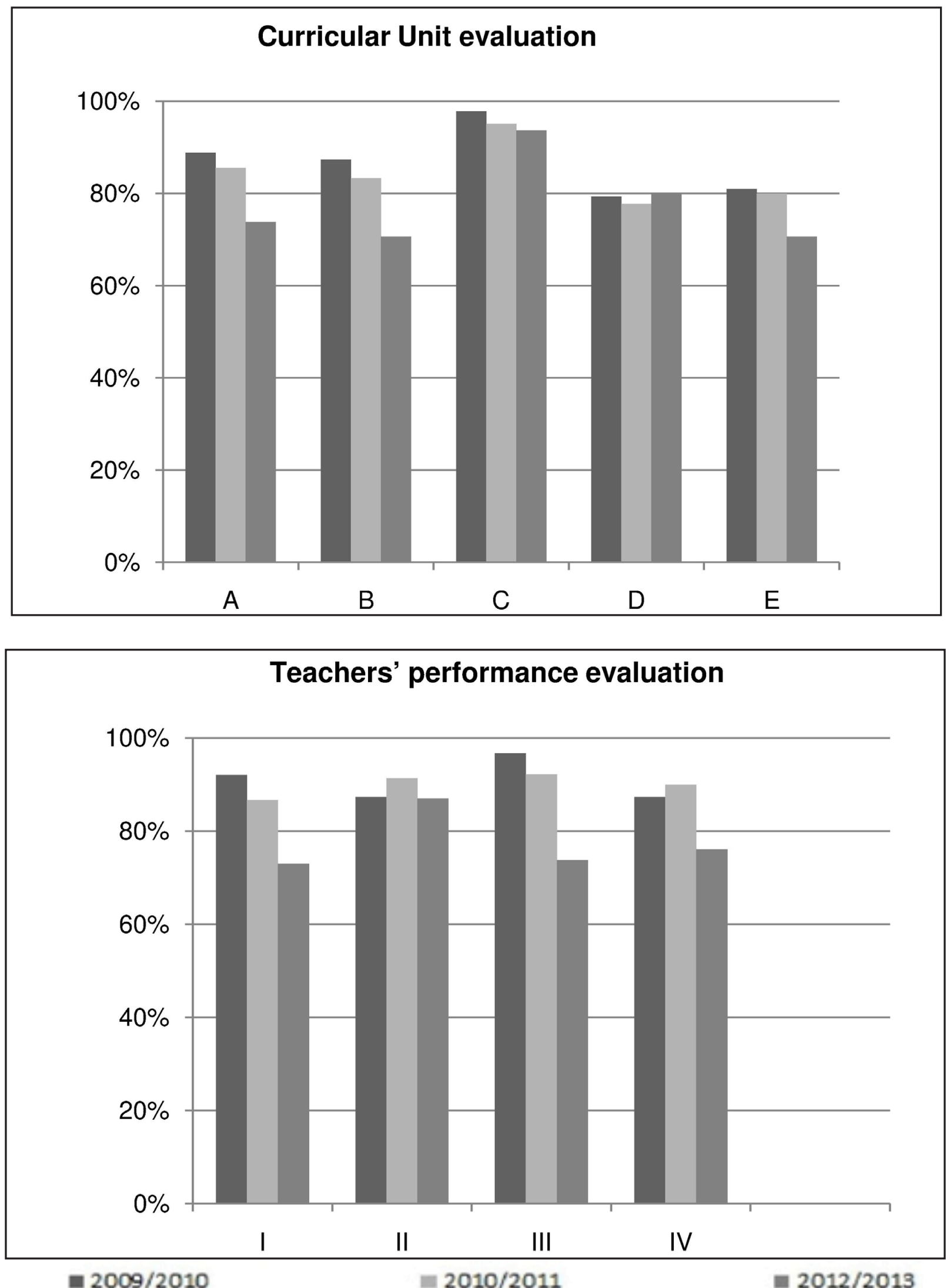

Figure 3: Quality assurance system: Curricular Unit (CU): A. Global functionality of the CU; B. Adequacy of the CU proposed activity to the defined objectives; C. Students assiduity degree to the tutorial classes; D. Global satisfaction degree concerning student performance; E. Students motivation for the CU. Teachers' performance: I. Global evaluation of the teacher performance; II. Fulfillment of the evaluation standing rule agreed with de students; III. Relationship between students and teacher; IV. Creation of a learning favorable atmosphere and to the active students participation. 
Given that the number of student we had exceeded the optimal quantity, as discussed above, we decided, by preceding experience, that it was advisable to have two smaller groups, thus comprising 6-8 students each group in the same classroom. ${ }^{14}$ The main reason for this preference was that, in smaller groups, the information was easily exchanged between all students. None the less, our teaching experience leads us to consider that session group with less than 6 students decrease the discussion throughput, resulting in less participative and monotonous sessions. Still, given that this strategy was implemented in previous editions of the course, ${ }^{8}$ students were more comfortable in adopting that system.

Furthermore, the Biomedical Sciences course curricular structure provided students the opportunity of transposing the information from previously taught curricular units. Hence, the active-learning process is cumulative and influenced by prior knowledge, providing the support for the problem analysis, self- directed learning and future learning. ${ }^{15,16}$

The seminars permitted the enthusiastic participation of the students, who were encouraged to interact with the experts by asking questions. Equally, the seminars gave to the students, the opportunity of contacting with professionals, exposing them to the labor-market. Moreover, the pharmaceutical industry visit was very interesting and highly motivating for the reason that students effectively visualized and materialized the knowhow integrated during the theoretical component of the unit. In essence, students felt motivated to learn, particularly in the context of MALA. This multi- faceted teaching method makes it possible to effectively embrace competences in the technical, scientific and pedagogic areas, given that theoretical students' knowledge were approached by specialists in pharmaceutical areas. Moreover, practical competences were acquired during the field- trip, promoting the development of students' technical skills. These so- named "hands on experience" schemes promote the students autonomy and the feeling of responsibility for the transmission of knowledge within working groups. Additionally, increased research autonomy, synthesis, integration, student assessment and discussion of knowledge were markedly noted.

\section{CONCLUSION}

In conclusion, the present study fostered the concept that the MALA- learning approach should contribute to knowledge- enhancing in the pharmaceutical practice and could encourage integration of the students' learn- ing skills in the future career, thus stimulating the flexibility in learning.

\section{ACKNOWLEDGEMENT}

The authors wish to express their sincere thanks to the students, without whom this study would not be possible, and to the experts who collaborate with this curricular unit.

\section{CONFLICTS OF INTEREST}

No conflicts of interest to declare.

\section{ABBREVIATION}

CEA: Complementary Education Activities

CTD: Common Technical Document

CU: Curricular Unit

EMA: European Medicines Agency

ICH: International Conference of Harmonization

INFARMED: National Authority of Medicines and Health Products, IP

LO: Learning Outcomes

MALA: Multi-method Active Learning Approach

PAT: Performance, Attributes and Tasks

PBL: Problem-based Learning

PDD: Pharmaceutical Drug Development

TS: Tutorial sessions

UA: University of Aveiro

\section{REFERENCES}

1. Accreditation Council for Pharmacy Education. Accreditation standards and guidelines for professional program in pharmacy leading to the doctor of pharmacy degree. Chicago, Illinois: ACPE; 2006. .

2. Gwee MC. Globalization of problem-based learning (PBL): cross-cultural implications. Kaohsiung J Med Sci. 2008 Mar; 24(3 Suppl): S14-22.

3. Meyers C, Jones TD. Case Studies, Promoting Active Learning-Strategies for the College Classroom. Jossey-Bass Washington, San Francisco; 1993. pp. 103-19.

4. Dolmans DH, De Grave W, Wolfhagen IH, van der Vleuten CP. Problembased learning: future challenges for educational practice and research. Med Educ. 2005 Jul; 39(7): 732-41.

5. Bowell C, Eison J. Active-Learning: Creating Excitement in the Classroom, AEHE-ERIC Higher Education Report No. 1 Jossey-Bass Washington, DC; 1991.

6. Bate E, Hommes J, Duvivier R, Taylor DC. Problem-based learning (PBL): getting the most out of your students - their roles and responsibilities: AMEE Guide No. 84. Med Teach. 2014 Jan; 36(1): 1-12.

7. Norman GR, Schmidt HG. The psychological basis of problem-based learning: a review of the evidence. Acad Med. 1992 Sep; 67(9): 557-65.

8. Fardilha M, Schrader M, da Cruz ESOA, da Cruz ESEF. Understanding fatty acid metabolism through an active learning approach. Biochem Mol Biol Educ. 2010 Mar; 38(2): 65-9.

9. Kennedy D, Hyland A, Ryan N. Writing and using learning outcomes. a practical guide. Berlim; 2007. 
10. Gijselaers W. Perspectives on problem-based learning. Educational Innovation in Economics and Business Administration; 1995. 39-52.

11. Albanese MA, Mitchell S. Problem-based learning: a review of literature on its outcomes and implementation issues. Acad Med. 1993 Jan; 68(1): 52-81.

12. Boud D, Feletti G, Eds. Changing Problem-Based Learning, Introduction to the Second Edition. Routledge; 1997. Millon Park.

13. Schmidt HG. Problem-based learning-Rationale and description Med Educ. Online.1983; 17: 11-6.
14. Haworth IS, Eriksen SP, Chmait SH, Matsuda LS, McMillan PA, King EA, et al. A problem based learning, case study approach to pharmaceutics: Faculty and student perspectives. American Journal of Pharmaceutical Education. 1998; 62(4): 398-405.

15. Whitley HP. A public health discussion series in an advanced pharmacy practice experience. American Journal of Pharmaceutical Education. 2010 Aug 10; 74(6): 101.

16. Yew EH, Chng E, Schmidt HG. Is learning in problem-based learning cumulative? Adv Health Sci Educ Theory Pract. 2011 Oct; 16(4): 449-64. 